Pobrane z czasopisma Annales N - Educatio Nova http://educatio.annales.umcs.pl Data: 26/04/2023 09:54:12

W Y D A W N I C T W O U M C S

\begin{tabular}{lc}
\hline & ANNALES \\
& UNIVERSITATIS MARIAE CURIE-SKŁODOWSKA \\
VOL. VI & LEBLIN - POLONIA \\
\hline
\end{tabular}

ISSN: 2451-0491 • e-ISSN: 2543-9340 • CC-BY 4.0 • DOI: 10.17951/en.2021.6.487-496

Multiplikowanie adresata utworów intencjonalnie skierowanych do młodego odbiorcy - szansa czy zagrożenie? W kontekście książki Hanny Dymel-Trzebiatowskiej „Filozoficzne i translatoryczne wędrówki po Dolinie Muminków" (2019)

Multi-Addressee Nature of Works Intentionally Aimed at a Young Audience - an Opportunity or a Threat? In the Context of Hanna Dymel-Trzebiatowska's "Philosophical and Translational Migrations in the Moomin Valley" (2019)

\title{
Dorota Michulka
}

\author{
Uniwersytet Wrocławski \\ Wydział Filologiczny \\ pl. Nankiera 15b, 50-140 Wrocław, Polska \\ dorota.michulka@uwr.edu.pl \\ http://orcid.org/0000-0002-7237-2618
}

\begin{abstract}
The article is based on the review of the book by Hanna Dymel-Trzebiatowska Philosophical and Translational Migrations in the Moomin Valley (2019). Interdisciplinary considerations concern the issue of the multi-addressee nature of works intentionally aimed at a young audience, and their basis is the analysis and interpretation of Tove Jansson's series on Moomins, deeply rooted in philosophical contexts. In the interpretation of the saga of the Finnish writer, Dymel-Trzebiatowska refers to various aspects of the theory and practice of reception as well as to selected issues belonging to the area of theory and practice of translation. In interpretative contexts, the researcher also distinguishes psychoanalytical critique, cognitive poetics, existential
\end{abstract}


philosophy, the broadly understood philosophy of ethics and childhood anthropology, thanks to which her book fits perfectly into contemporary discussions on the function, place, role and status of children's literature, its meaning in the wider cultural circuit literary and - potentially - also its presence in the field of Polish studies.

Keywords: multi-addressee; children's literature; theory and practice of translation; psychoanalytic critique; childhood anthropology

\begin{abstract}
Abstrakt. Artykuł powstał w oparciu o recenzję książki Hanny Dymel-Trzebiatowskiej Filozoficzne i translatoryczne wędrówki po Dolinie Muminków (2019). Interdyscyplinarne rozważania dotyczą kwestii wieloadresowości utworów intencjonalnie skierowanych do młodego odbiorcy, a ich podstawą jest analiza i interpretacja zakorzenionej głęboko w kontekstach filozoficznych serii Tove Jansson o Muminkach. W interpretacji sagi fińskiej pisarki Dymel-Trzebiatowska odwołuje się do różnych aspektów teorii i praktyki recepcji oraz wybranych zagadnień przynależnych do obszaru teorii i praktyki przekładu. Badaczka w kontekstach interpretacyjnych wyróżnia także krytykę psychoanalityczną, poetykę kognitywną, filozofię egzystencjalną, szeroko pojętą filozofię etyki oraz antropologię dzieciństwa, dzięki czemu jej książka wpisuje się znakomicie we współczesne dyskusje na temat funkcji, miejsca, roli i statusu literatury dziecięcej, jej znaczenia w szerszym obiegu kultury literackiej oraz - potencjalnie - także jej obecności w obszarze edukacji polonistycznej.
\end{abstract}

Słowa kluczowe: wieloadresowość; literatura dziecięca; teoria i praktyka przekładu; krytyka psychoanalityczna; antropologia dzieciństwa

Książka Hanny Dymel-Trzebiatowskiej Filozoficzne i translatoryczne wędrówki po Dolinie Muminków (2019) bardzo dobrze wpisuje się we współczesne dyskusje na temat funkcji, miejsca, roli i statusu literatury dziecięcej, jej znaczenia w szerszym obiegu kultury literackiej oraz zakresu prowadzonych nad tą literaturą interdyscyplinarnych badań o zasięgu międzynarodowym, podejmowanych głównie z perspektywy literaturoznawczej, filozoficznej i translatologicznej, tym bardziej że przekłady i adaptacje literatury dla dzieci od wielu lat wzbudzają dyskusje, kontrowersje i polemiki. Dziecko jest czytelnikiem niedoświadczonym literacko, ale „świeżym” i ciekawym świata, dlatego uwagi dotyczące przekładów i adaptacji utworu literackiego z zakresu literatury dla młodego odbiorcy są obecnie nad wyraz aktualne we współczesnym dziecięcym i młodzieżowym odbiorze czytelniczym oraz w świetle badań literaturoznawczych (między innymi ze względu na mnogość przekładów, obfitość utworów opowiedzianych na nowo, odczytanych inaczej, powtórzonych czy „przepisanych” w inny sposób [re-telling, re-writing, re-reading]) (Cornis-Pope 1992; Woźniak 2013).

Rozważania autorki koncentrują się wokół literackiego fenomenu, arcydzieła jedynego w swoim rodzaju - dziewięciotomowej serii/sagi Tove Janson o Muminkach. Dymel-Trzebiatowska (2019: 107) słusznie podkreśla, że „[d]ziewięć tomów muminkowej historii stanowi dojrzewającą, ewoluującą serię, której wszystkie walory i subtelności można dojrzeć, poznając ją chronologicznie”. 
Analizy i interpretacje utworów Jansson, które przeprowadza Dymel-Trzebiatowska, są niezwykle wnikliwe i głęboko zakorzenione w interdyscyplinarności badań. Oprócz eksploracji natury literaturoznawczej, filozoficznej i translatologicznej wpisują się wyraźnie także w problematykę związaną z ludzką egzystencją, doświadczeniem estetycznym, oddziaływaniem biografii twórcy na artystyczną kreację jego utworów, poza tym odwołują się do różnych koncepcji „natury” dziecka i „esencji” dzieciństwa, do kreowania społeczno-kulturowego obrazu dzieciństwa oraz jego doświadczania - ujętego w pracy również z perspektywy dorosłego człowieka, a przede wszystkim „pokazują” obraz dziecka, które staje się specyficznym odbiorcą dzieła literackiego.

Istotną rolę w badaniach Dymel-Trzebiatowskiej, w odniesieniu do muminkowej sagi, odgrywa zagadnienie niejako „multiplikowanego” adresata utworu, którym może być czytelnik w różnym wieku (na przykład dziecko, nastolatek czy dorosły), a także teoria i praktyka recepcji (Nikolajeva 2014). Książka tej badaczki ma solidną i precyzyjną strukturę, a kompozycja wywodu jest znakomicie przemyślana. Monografia wyróżnia się jasno postawioną naukową tezą, klarownym układem problemów badawczych oraz czytelnym porządkiem omawianych zagadnień. Opracowanie liczy 226 stron, znajduje się w nim imponująca bibliografia przedmiotowa oraz indeks osobowy.

Rozprawa Hanny Dymel-Trzebiatowskiej została podzielona na dwie części, których problematykę wyznacza tytuł monografii. Są to wędrówki filozoficzne i wędrówki translatoryczne, a w ich ramach znajdują się klarownie skonstruowane rozdziały.

W części Wędrówki filozoficzne dla przykładu, przygotowanej w kontekście szeroko rozumianej intertekstualności analiz i interpretacji, badaczka odnosi się do pojęć hipotekstów, eksplicytnych i implicytnych, które można odnaleźć w serii o Muminkach, a w dziesięciu kolejnych rozdziałach przypisanych do tej części znajdują się odwołania do badań: Oswalda Spenglera, Ortegi y Gasseta, Sokratesa, Henri'ego Bergsona, Parmenidesa, Edvarda Westermarcka, Michaiła Bachtina, Karen Horney, Antoniego Kępińskiego, Carla Gustava Junga, Sigmunda Freuda i Normana Hollanda. W filozoficznej części rozważań autorka przywołuje kolejno następujące zagadnienia, będące jednocześnie tytułami klarownie opracowanych rozdziałów: Katastrofizm, Witalność i wolność, Piękno, sztuka i jej twórcy, W poszukiwaniu sprawiedliwości, Życie snem, Triumf życia nad śmiercia, Niewidzialni, Nie ma życia bez lęku, Kryzys, Pożegnanie.

Tak szeroko zarysowany filozoficzny i intertekstualny kontekst interpretacyjny książki (podejmujący między innymi aspekty psychoanalizy czy teorię 
i praktykę odbioru) pozwala na uwzględnienie w kontekście czytelniczej recepcji słynnej serii Jansson doświadczonego odbiorcy dziecięcego (niejako przygotowanego do rozumienia szerszych kontekstów antropologicznych czy egzystencjalnych) oraz oczywiście odbiorcy dorosłego.

Dymel-Trzebiatowska zastanawia się i rozważa konsekwentnie w drugiej części swojego opracowania, w jaki sposób ten „podwójny zwrot” (wieloadresowy odbiorca) został uwzględniony również w przekładzie serii o Muminkach.

Zjawisko dwuadresowości (dziecka i dorosłego) i wieloadresowości (odbiorcy w różnym wieku) utworu intencjonalnie skierowanego do młodszych czytelników - co sygnalizuje badaczka - zostało już omówione w badaniach teoretycznoliterackich i ukazuje dość szeroki zakres pojęć związanych z tym zagadnieniem. W opracowaniach literaturoznawczych odnoszących się do kwestii odbiorcy tego typu tekstów wyróżniono między innymi następujące terminy: ambivalence (ambiwalencja) (Shavit 1986), trójdzielna taksonomia, dual, double i single addresss, czyli zwrot podwójny, pojedynczy i dwojaki (Wall 1991), shadow text (tekst-cień) (Nodelman 2008), multiple address (wielorakizwrot) (O'Sullivan 2005) czy crossover literature (literatura transgresywna) (Beckett 2009, 2012).

Zagadnienie recepcji utworu literackiego i dialogu, jaki toczą między sobą tekst i czytelnik, rozważane jest od wielu lat. W szerszym kontekście literaturoznawczym kwestia odbioru dzieła stała się problemem rozpatrywanym między innymi przez socjologię literatury (por. pojęcie literatury z perspektywy czytelnika w ujęciu na przykład Haralda Weinricha [1972]) oraz zagadnieniem podejmowanym przez reprezentantów niemieckiej szkoły estetyki recepcji (por. terminy: horyzont oczekiwań i czytelnik wpisany w tekst) (Iser 1978; Jauss 1999; Weinrich 1972).

Warto zwrócić uwagę w tym miejscu rozważań także na aspekt „czytelnika realnego" (Maryl 2007). Zofia Budrewicz, literaturoznawczyni i dydaktyk literatury, omawiając kwestie odbioru utworu literackiego z perspektywy edukacji polonistycznej, zauważa: „Sytuację odbioru dzieła artystycznego wyprowadza [się już] z antropologii literatury i kulturowej teorii literatury [...]. Autorzy wielu prac [zmierzając $\mathrm{w}$ stronę poznawania przez doświadczenie] wiążą operacyjną przydatność figury podmiotowego doświadczenia sensualno-mentalnego z możliwościami »wglądu« w nie odbiorcy - ucznia" (Budrewicz 2012: 6), emocjonalnego zaangażowania realnego czytelnika, czytania empatycznego i afektów (Koziołek 2016; Miall 2006; Opdahl 2002; Paivio 1971, 1991). Wydaje się, że saga o Muminkach wpisuje się w ten kontekst rozważań znakomicie, ponieważ zarówno uwzględnia wyraziste portrety psychologiczne postaci, które niejako „zapraszają" młodego odbiorcę do empatycznego ustosunkowania się wobec nich, jak i prezentuje figury bohaterów literackich, z którymi dziecięcy czytelnik może się „emocjonalnie” utożsamić. Wyzwaniem dla młodego odbiorcy staje 
się również dostrzeżenie i zrozumienie szerokiej perspektywy rozważań natury egzystencjalno-etycznej podjętej w sadze o Muminkach.

Dymel-Trzebiatowska, podkreślając w swej rozprawie psychoanalityczny aspekt odbioru tekstu literackiego i „wpisując” sagę Jansson w ten obszar rozważań, przywołuje publikację Normana Hollanda The Dynamics of Literary Response (1989).

Holland, teoretyk literatury oraz znawca krytyki psychoanalitycznej i poetyki kognitywnej, zdaniem autorki odkrywa „psychodynamiczną interpretację percepcji literatury, opartą na kilku konceptach psychologii Freuda" (Dymel-Trzebiatowska 2019: 95), twierdząc, że naturalność i świeżość procesu odbioru literatury pozwala na konstatację, iż „stajemy się [wtedy] dziećmi” (Holland 1989: 80). Badacz teorii i praktyki recepcji dodaje, że „pisarz w swoich utworach zawiera własne fantazje, które - jeśli czytelnik dzieli je z nim - zostaną przez niego rozpoznane" (Dymel-Trzebiatowska 2019: 95-96), co pozwala na odczuwanie nie tylko przyjemności, lecz także zadowolenia i spełnienia sięgającego stanów podświadomości. Holland odnosi się w tym miejscu do kwestii mechanizmów obronnych, które charakteryzują psychikę ludzką i pisze:

Tekst, jednakowoż, nie przedstawia nam pierwotnej fantazji, ale raczej jej wersję zmodyfikowaną i ukształtowaną przez manipulacje, które w literaturze określane są jako „forma”, a które przypominają mechanizmy obronne w ludzkiej psychice. Ostatecznie to właśnie autor w akcie doświadczania i spisywania fantazji umieszcza ją w tekście w formie obronnej [...]. Zdaje się on mieć dwa rodzaje więzi z tekstem. Na poziomie świadomym jest aktywnie zaangażowany w jej postrzeganie i nadawanie znaczeń swoim percepcjom. Nieświadomie tekst konfrontuje go z fantazjami i mechanizmami obronnymi, takimi samymi jak te w jego umyśle. (Holland 1989: 62)

Dokładniej rzecz biorąc, mechanizm obronny to proces, który ego uruchamia na sygnał niebezpieczeństwa ze świata zewnętrznego, id i superego. Oczywiście coś takiego ma miejsce w umyśle, a nie w tekście literackim. Jednak to, do czego doszliśmy, to fakt, że utwory literackie ucieleśniają fantazje znane z doświadczeń psychoanalitycznych i radzą sobie z nimi przy użyciu technik, które przypominają strategie obronne i adaptacyjne. (Holland 1989: 57-58, cyt. za: Dymel-Trzebiatowska: 95-104)

W ten obszar rozważań odnoszących się do kontekstów interpretacyjnych, obejmujących także światy wewnętrzne i psychologię postaci literackich, zdaniem Dymel-Trzebiatowskiej bardzo dobrze wpisuje się saga o Muminkach. 
W drugiej części monografii - Wędrówki translatoryczne - autorka w sposób wnikliwy odwołuje się do badań polskich tłumaczeń wybranych zagadnień językowych, które uznaje za najistotniejsze dla poetyki całej sagi. W tym kontekście wymienia: antroponimy (w podrozdziale zatytułowanym Nie tylko o Pizmowcu, który (nie) jest Piżmakiem), komizm (na przykład w podrozdziale zatytułowanym Niepaszczackie wybory) oraz zwyczaje kulinarne (zdaniem badaczki wiążą się one między innymi z postacią Mamusi Muminka, figurą matki-żywicielki, która dzięki swemu zaangażowaniu w przygotowywanie posiłków wpływa na budowanie dobrych relacji panujących w rodzinie oraz na tworzenie pozytywnej atmosfery ogniska domowego). Jak pisze Dymel-Trzebiatowska:

Inteligentny komizm jest jednym z dystynktywnych i zarazem najmocniejszych walorów książek o Muminkach i jego optymalnie dokładny przekład można potraktować jako bardzo istotny aspekt, umożliwiający doświadczenie estetyczne potencjału sagi. W tym segmencie oszacowanie przesunięć translacyjnych nie było łatwym zadaniem, ponieważ część wyborów zdaje się być podyktowana uwzględnieniem kompetencji i dobra dzieci (np. [...] redukcja słowa memuary i będąca jej implikacją modyfikacja dialogu Mamusi i Tatusia Muminka), część z kolei zachowuje treści potencjalnie dla nich za trudne lub niewskazane (skomplikowane stylistycznie wypowiedzi Tatusia - narratora pamiętników, czarny humor Małej Mi). (Dymel-Trzebiatowska 2019: 215)

W translatorycznej części wypowiedzi badaczka wnikliwie analizuje znaczące dla tej dziedziny nauki terminy, na przykład omawia przekłady filologiczne, pojęcie przeniesienia oraz jego hybrydy, kwestie transkrypcji i substytucji, zastanawiając się jednocześnie nad zagadnieniem wierności i niewierności przekładu czy nad adaptacjami utworów literackich. W szerszym kontekście metodologicznym Dymel-Trzebiatowska przywołuje znaczące dla teorii i praktyki przekładu publikacje skandynawskich uczonych, na przykład opracowanie Göte Klingberga Children's Fiction in the Hands of the Translators (1986) czy Riitty Oittinen Translating for Children (2000), w których określono między innymi model domyślnego czytelnika czy też koncept wizerunku dziecka (child image).

Przedstawiciele dwóch skandynawskich nurtów teorii przekładu dla dzieci, nazwanych „szkołą niewierności i wierności” (Nikolajeva 2003), Riitta Oittinen i Göte Klingberg, budują swoje koncepcje na założeniu odrębności i wyjątkowości dziecka jako innego czytelnika. [...] Wizerunek dziecka jest centralnym 
czynnikiem przekładu książek dziecięcych: zgodnie ze swoją ideologią tłumacze kierują słowa do pewnego rodzaju dziecka. (Oittinen 2006: 41, cyt. za: Dymel-Trzebiatowska: 216-217).

W perspektywie porównania adresata tekstu źródłowego i docelowego, w niezwykle precyzyjny sposób w trakcie prowadzonych analiz Dymel-Trzebiatowska omawia pojęcia leksemów lub fraz, podejmuje kwestie techniki przekładu oraz zagadnienia przesunięcia semantycznego lub/i formalnego. Logiczna konstrukcja rozważań pozwoliła na sformułowanie w konkluzji pracy syntetycznych i problematyzujących poszczególne zagadnienia wniosków wraz z głębszą refleksją związaną z implikacjami wieloadresowości dla translatoryki.

Książka Filozoficzne i translatoryczne wędrówki po Dolinie Muminków prowokuje do podejmowania szerszych dyskusji na temat wieloadresowości przekładów literatury dla młodego czytelnika oraz statusu tekstów dla niego pisanych. Autorka stawia bowiem na koniec swoich rozważań istotne pytania czy też wyzwania na przyszłość, na przykład:

Czy rosnąca wieloadresowość może zachwiać paradygmatem dziecięcego czytelnika jako dystynktywnym elementem literatury dziecięcej i doprowadzić do zaniku tradycyjnej dychotomicznej taksonomii dzielącej literaturę na: dla dzieci i dla dorosłych? Czy wieladresowość należy uwzględniać przy przekładzie każdej książki dla dzieci, czy jest ona raczej cechą typową tylko dla książek artystycznych, nagradzanych i określanych jako literatura wysokojakościowa? (Dymel-Trzebiatowska 2019: 217-218)

Ponadto z przeprowadzonych przez Dymel-Trzebiatowską analiz i interpretacji dokonanych już przekładów literatury skandynawskiej wynika klarowna teza, przyjmująca kształt przekonującego postulatu. Jest nim potrzeba wyższej kompetencji koherencyjnej tłumaczy. Badaczka konstatuje:

Przez kompetencję koherencyjną rozumiem wariant kompetencji kognitywnej, czyli umiejętności gromadzenia „wiedzy, której nabywa odbiorca tekstu w miarę jego poznawania" (Pisarska, Tomaszkiewicz 1996: 68). Ten naturalny proces dokonuje się samoistnie podczas czytania ze zrozumieniem i sprowadza do łączenia faktów w obrębie świata przedstawionego utworu. Uzasadnieniem rozróżnienia odrębnego terminu jest - moim zdaniem - kojarzenie, rozpoznawanie i zapamiętywanie przez tłumaczy na przestrzeni całego tekstu: informacji oraz form językowych opisujących je, a następnie dokonywanie konsekwentnej, przemyślanej re-ekspresji. (tamże: 210) 
Konkludując, monografia Dymel-Trzebiatowskiej na gruncie polskich badań translatologicznych jest nie tylko opracowaniem wyjątkowo dojrzałym naukowo, przekonującym filologicznie, logicznie, jasno i klarownie skonstruowanym, lecz także pracą nowatorską, innowacyjną i niezwykle erudycyjną w partiach analityczno-interpretacyjnych. Może być wykorzystana zarówno w naukowych eksploracjach przez literaturoznawców, badaczy teorii i praktyki przekładu, jak i w praktykach lekturowych nauczycieli w obszarze szkolnej edukacji polonistycznej. Wszak saga o Muminkach od lat jest popularną lekturą szkolną.

Autorka książki Filozoficzne i translatoryczne wędrówki po Dolinie Muminków jako literaturoznawczyni oraz badaczka teorii i praktyki przekładu jest wyjątkowo staranna i przenikliwa - sumiennie omawia w przypisach szersze konteksty używanych przez siebie naukowych definicji, powołując się na bardzo bogatą literaturę przedmiotu. Duże wrażenie robi w rozważaniach autorki metodologiczne zaplecze jej książki, międzynarodowość ujęć, ich interdziedzinowość, a także wielka dbałość i troska o precyzję rozumienia wprowadzanych do wypowiedzi terminów oraz o szatę redakcyjną i edytorską opracowania.

Hanna Dymel-Trzebiatowska używa zgrabnej, wdzięcznej i dojrzałej naukowo polszczyzny oraz posługuje się jasnym i klarownym stylem. Książka jest potwierdzeniem znakomitego przygotowania merytorycznego autorki, charakteryzuje się rzetelnością, wnikliwością i innowacyjnością, napisana została z wielkim znawstwem, zaangażowaniem i pasją. W swych rozważaniach badaczka w sposób nowatorski umiejętnie łączy szczegółowe analizy materiału z szerszą perspektywą ujęć naukowych eksploracji literaturoznawcy, kompetentnie i profesjonalnie „integruje” swe historycznoliterackie interpretacje z teorią przekładu, filozofią i etyką, antropologią literatury, psychoanalizą i estetyką oraz krytyką literacką, ukazując wieloaspektowy i wielopoziomowy, a jednocześnie pełny, spójny i syntetyczny obraz problemu postawionego w tytule książki. 


\section{BIBLIOGRAFIA}

\section{Literatura}

Beckett, S. (2009). Crossover Fiction: Global and Historical Perspectives. New York: Routledge.

Beckett, S. (2012). Crossover Picturebooks: A Genre for All Ages. New York: Routledge. Budrewicz, Z. (2012). Odbiorca szkolnej lektury jako podmiot doświadczający. W: K. Biedrzycki, A. Janus-Sitarz (red.), Doświadczenie lektury. Między krytyką literacka a dydaktyka literatury (s. 63-73). Kraków: Universitas.

Cornis-Pope, M. (1992). Hermeneutic Desire and Critical Rewriting: Narrative Interpretation in the Wake of Poststructuralism. London: Palgrave Macmillan.

Dymel-Trzebiatowska, H. (2019). Filozoficzne i translatoryczne wędrówki po Dolinie Muminków. Gdańsk: Wydawnictwo Uniwersytetu Gdańskiego.

Holland, N. (1989). The Dynamics of Literary Response. New York: Columbia University Press.

Iser, W. (1978). The Act of Reading: The Theory of Aesthetic Response. London-Baltimore: The Johns Hopkins University Press.

Jauss, H.R. (1999). Historia literatury jako prowokacja. Przeł. M. Łukasiewicz. Warszawa: Wydawnictwo IBL.

Klingberg, G. (1986). Children's Fiction in the Hands of the Translators. Lund: Gleerup. Koziołek, K. (2016). Czas lektury. Katowice: Wydawnictwo Uniwersytetu Ślaskiego.

Miall, D. (2006). Literary Reading: Empirical and Theoretical Studies. New York: Peter Lang, August.

Nikolajeva, M. (2003). Verbal and Visual Literacy: The Role of Picturebooks in the Reading Experience of Young Children. W: N. Hall, J. Larson, J. Marsh (eds.), Handbook of Early Childhood Literacy (s. 235-248). London: SAGE Publications Ltd.

Nikolajeva, M. (2014). Reading for Learning: Cognitive Approaches to Childrens Literature. London: John Benjamins Publishing Company.

Nodelman, P. (2008). The Hidden Adult: Defining Children's Literature. Baltimore: Jones Hopkins University Press.

O'Sullivan, E. (2005). Comparative Children's Literature. London - New York: Routledge. Oittinen, R. (2000). Translation for Children. New York: Garland.

Oittinen, R. (2006). The Verbal and the Visual: On the Carnivalism and Dialogics of Translating for Children. W: G. Lathey (ed.), The Translation of Children's Literature: A Reader (s. 84-141). Ontario: Multilingual Matters.

Opdahl, K. (2002). Emotion as Meaning: The Literary Case for How We Imagine. LondonCranbury: Bucknell University Press Associated University Presses.

Paivio, A. (1971). Imagery and Verbal Processes. New York: Psychology Press.

Paivio, A. (1991). Images in Mind: The Evolution of a Theory. New York - London: Harvester Wheatsheaf.

Pisarska, A., Tomaszkiewicz, T. (1996). Wspótczesne tendencje przekładoznawcze. Poznań: Wydawnictwo Naukowe UAM. 
Pobrane z czasopisma Annales N - Educatio Nova http://educatio.annales.umcs.pl Data: 26/04/2023 09:54:12

Shavit, Z. (1986). Poetics of Children's Literature. Athens-Georgia: University of Georgia Press.

Wall, B. (1991). The Narrator's Voice: The Dilemma of Children's Fiction. New York: St. Martin's Press.

Weinrich, H. (1972). O historię literatury z perspektywy czytelnika. Przeł. R. Handke. Teksty, nr 4, 157-168.

Woźniak, M. 2013. Adaptacja w przekładach dla dzieci - gawęda terminologiczna. Filoteknos: literatura dziecięca, mediacja kulturowa, antropologia dzieciństwa, $\mathrm{nr} 3$, 22-35.

\section{Netografia}

Maryl, M. (2007). Interpretator czy czytelnik? Projekt badań empirycznych nad stylami odbioru. Pobrane z: www.academia.edu/5544682/Interpretator_czy_czytelnik_ Projekt_bada\%C5\%84_empirycznych_nad_stylami_odbioru [dostęp: 10.02.2021]. 